\title{
CHARACTERIZATION OF NUTRITION, ANTIOXIDANT PROPERTIES, AND TOXICITY OF PHYSALIS ANGULATA L. PLANT EXTRACT
}

\author{
ADE CHANDRA IWANSYAH ${ }^{1 *}$, WAHIDIYANTI PUTRI JULIANTI ${ }^{2}$, ROHMAH LUTHFIYANTI $^{1}$ \\ ${ }^{1}$ Research Centre for Appropriate Technology, Indonesian Institute of Sciences, Jl. KS Tubun No. 5 Subang 41213, West Java - Indonesia. \\ ${ }^{2}$ Department of Food Technology, Faculty of Engineering, Pasundan University, Jl. Dr. Setiabudi Street No. 193, Bandung, West Java \\ Indonesia. Email: chandra.iwansyah@gmail.com \\ Received: 28 August 2019, Revised and Accepted: 16 September 2019
}

ABSTRACT

Objective: This research was to characterize and compare the nutrition, total phenolics (TP) content, antioxidant activity, and toxicity of all part of Physalis angulata L. extract.

Methods: The proximate, minerals, TP content, antioxidant activity, and toxicity of all parts of physalis, namely, stem bark extract of $P$. angulata L. (ESC), leaf extract of $P$. angulata L. (ELC), rind extract of $P$. angulata L. (ERC), unripe fruit extract of $P$. angulata L. (EUF), and ripe fruit extract of P. angulata L. (EFC), were analyzed. The TP content, total flavonoids (TF), and free radical scavenging activity of ethanolic extract are studied using Folin-Ciocalteu assay, aluminum chloride assay, and 1,1-diphenyl 2-picrylhydrazyl scavenging assay. Brine shrimp lethality bioassay (LC ${ }_{50}$ ) used to measure the toxicity of extract.

Results: The physalis leaves extract (ELC) contains the highest total of phenolics (144.4 mg galiic acid equivalent/g), a total of flavonoids (33.33 mg quercetin equivalent $/ \mathrm{g})$, and antioxidant activity $(96.97 \mu \mathrm{g} / \mathrm{ml})$ followed by $\mathrm{ERC}>\mathrm{EFC}>\mathrm{EUF}>\mathrm{ESC}_{\text {. Based on the level toxicity of LC }}$, the ripe fruit extract of $P$. angulata (EFC) $(924.18 \mu \mathrm{g} / \mathrm{ml})$ valued as cytotoxic.

Conclusion: The data of nutrition, antioxidant properties, and toxicity of all parts of $P$. angulata extract provide for functional food product uses.

Keywords: Antioxidant, Ciplukan, Physalis angulata, Phytochemical, Toxicity.

(C) 2019 The Authors. Published by Innovare Academic Sciences Pvt Ltd. This is an open access article under the CC BY license (http://creativecommons. org/licenses/by/4. 0/) DOI: http://dx.doi.org/10.22159/ajpcr.2019.v12i11.35497

\section{INTRODUCTION}

In Indonesia, in the past three decades, there has been an increase in the use of herbal medicine products and supplements. To improve the quality of health, $80 \%$ of the world population uses plant products [1]. Alternative therapy was developed by taking into bioactive compounds derived from nature. The biodiversity found in Indonesia is the world's second order. A total of 2500 of 30,000 plants are medicinal plants [2]. With biodiversity, it is potential to develop functional food products. In Indonesia, at 2009-2011, functional food products have an increased [3].

Globally, a nutritional transition has occurred from infectious disease patterns toward chronic and degenerative lifestyle-related diseases [4]. In Indonesia, changes in nutritional transition are reinforced by increased non-communicable diseases, such as hypertension from $7.6 \%$ in 2007 to $9.5 \%$ in 2013; stroke from 8.3/1000 to $12.1 / 1000$ (2013); and diabetes mellitus from $1.1 \%$ (2007) to $2.1 \%$ (2013) [5]. One of the utilizations of traditional medicine based on local wisdom is using a plant named Physalis angulata Lour.

P. angulata L. (Indonesia: “Ciplukan" or Sundanese: "Cecendet"), family Solanaceae, empirically already utilized in Sundanese traditional medicine preparation for recovery "kencing manis" (diabetes mellitus). Previous studies have reported that physalis leaves possess an antidiabetic effect [6]. According to Pinto et al. [7], the ethanolic fruit extract of physalis has given anti-hyperglycemic and anti-hypertension potential. Moreover, the ethanolic crude extract of the fruit of physalis has a role in the immune system (immunomodulation), antiinflammation effect, and antioxidant activity $[8,9]$.

The utilization of local wisdom, increased demand, and many benefits obtained from physalis make it potentially functional food [9]. However, there are still challenges that must be faced, such as poor quality control of extract (non-standard), the lack of clinical and pharmacological data, and toxicity [10]. Nevertheless, based on our knowledge, the evaluation of characteristics antioxidant activity and toxicity of all parts of physalis remain scarce. The present study focused on evaluation and comparison of the characteristics of the nutrition, total phenolics (TP) content, antioxidant activity, and toxicity of all part of P. angulate Lour. Based on the results of the research, there was an effect of TP content against free radical scavenging activity at physalis extract.

\section{MATERIALS AND METHODS}

\section{Reagents and materials}

Folin-Ciocalteu's phenol reagent, 1,1-diphenyl 2-picrylhydrazyl (DPPH), gallic acid, quercetin was obtained from Sigma-Aldrich (Singapore). Artemia salina L. larva (Hobby Artemix) was purchased from Dohse Aquaristik GmbH and CO. Gelsdorf, Germany. Aluminum chloride, ethanol, sodium hydroxide, and sodium carbonate are obtained from Merck, Tbk. All reagent used is an analytical grade. Fresh $P$. angulata L (physalis) was collected from Rawalele village - Subang, Indonesia, obtained from January to May 2018 (Fig. 1). Botanical authentication was done by a Botanist from "Herbarium Bogoriense," Research Center for Biology, Indonesian Institute of Sciences (No. 886/IPH.1.01/If.07/IV/2018), with the voucher specimen that has been stored.

\section{Sample preparation}

Fresh physalis washed, then dried at $45^{\circ} \mathrm{C}$ in 3 days and smashed into powder, the powder soaking in ethanol with ratio $1: 10$ for $24 \mathrm{~h}$ by maceration methods ( 3 times). The filtrates were consolidated and dried by a vacuum evaporator. For analysis, $10 \mathrm{ml}$ of ethanol was added into a centrifugation tube containing $0.06 \mathrm{~g}$ of physalis ethanol extract. The samples centrifuged for $10 \mathrm{~min}$ after shaking. The resulting 


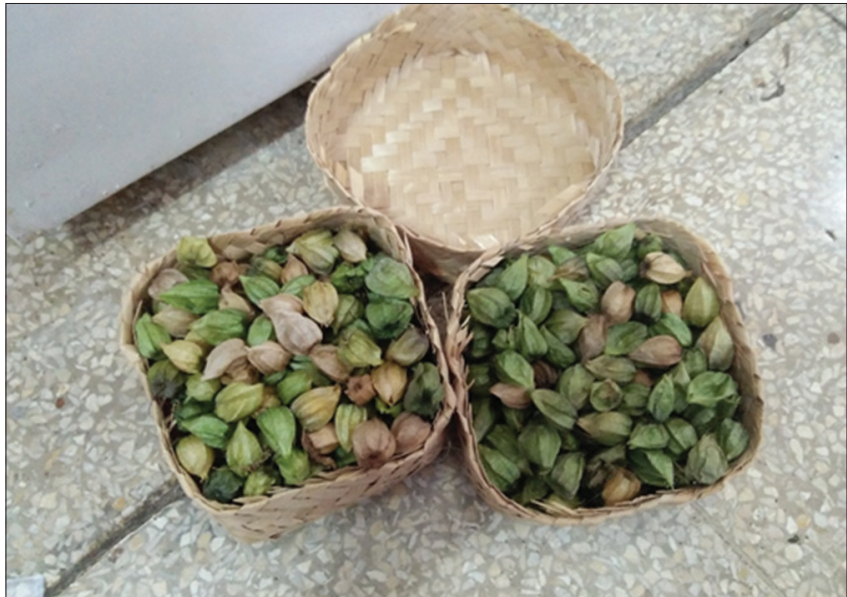

Fig. 1: Physalis angulata Lour

supernatant was inserted into a $10 \mathrm{~mL}$ volumetric flask and added ethanol to the limit mark and shaken for $10 \mathrm{~min}$ [11].

\section{Procedure analysis}

Physical and nutritional composition

Physical composition, namely, yield, $\mathrm{pH}$, total solid, and color was performed in triplicate. The nutrition composition, viz., moisture, ash, carbohydrates, protein, and lipid content, was measured by methods described [12]. Atwater factor used as a direct application in measuring the energy, which $1 \mathrm{~g}$ carbohydrate= $4 \mathrm{kcal}$; $1 \mathrm{~g}$ lipid=9 kcal; and $1 \mathrm{~g}$ protein $=4 \mathrm{kcal}$. Colorimeter $3 \mathrm{nh}$ is needed to determine the total color difference of the three coordinates.

\section{Preliminary phytochemical screening}

Physalis powder was the identification of saponin, flavonoid, alkaloids, tannin, glycosides, and sterols or terpenoids [13-15].

\section{Total carotenoids content}

Total carotenoid content of the extract studied with methods of Scrob et al. [16]. The extract of physalis was re-extracted with petroleum ether. The total carotenoid content of the samples was analyzed at $\lambda=450 \mathrm{~nm}$ using a ultraviolet (UV)-VIS spectrophotometer (UV-1700 Shimadzu series) in units of $\mu \mathrm{g} / \mathrm{g}$ (the absorbance should be between 0.2 and 0.8 ).

\section{TP content}

The TP content of physalis was analyzed with the Folin-Ciocalteu assay [17]. The $100 \mu \mathrm{l}$ extract or standard solution of gallic acid or blank $(0 ; 25 ; 50 ; 100 ; 150$; and $200 \mu \mathrm{g} / \mathrm{ml})$ has been added with distilled water $(2.8 \mathrm{ml})$ and sodium carbonate (2 $\mathrm{ml}$ and $2 \%)$, and allowed to stand for $4 \mathrm{~min}$. The $100 \mu \mathrm{l}$ of Folin-Ciocalteu solution was added, then silence for $30 \mathrm{~min}$. Measurement of blank solution was carried out at $\lambda=760 \mathrm{~nm}$. Total phenol is calculated based on equation one expressed in $\mathrm{mg}$ gallic acid equivalent (GAE) in grams of dry weight of plant extracts $\left(R^{2}: 0.994\right)$. The samples were analyzed in three replications.

$$
\text { Absorbance }=0.0005 \text { galiic acid } \frac{\mu \mathrm{g}}{\mathrm{mL}}-0.0033
$$

\section{TF content}

The TF content of physalis was determined using aluminum chloride assay [18]. The $1 \mathrm{ml}$ extract or standard solution of quercetin or blank $(0 ; 25 ; 50 ; 100$; and $200 \mu \mathrm{g} / \mathrm{ml})$ has been added with aluminum chloride ( $2 \mathrm{ml}$ and $2 \%$ ) in methanol solution. It was then mixed with vortex and allowed to stand for $30 \mathrm{~min}$. Measurement of blank solution was carried out at $\lambda=415 \mathrm{~nm}$. Flavonoid calculations according to the equation of two expressed in mg quercetin equivalent (QE) in gram dry weight of plant extracts $\left(\mathrm{R}^{2}: 0.993\right)$. The samples were analyzed in three replications.

$$
\text { Absorbance }=0.0081 \text { quercetin }\left(\frac{\mu g}{m L}\right)+1.594
$$

\section{Antioxidant activity}

Analysis of antioxidant activity in physalis extracts using the method [19]. The extract solution at concentrations is not the same $(1 \mathrm{ml})$ or blank or standard solution has been added with $3 \mathrm{ml}$ of $0.004 \%$ DPPH methanolic solution then stored in the dark for $30 \mathrm{~min}$. Measurement of blank solution was carried out at $\lambda=517 \mathrm{~nm}$. Data obtained were calculated by expression (30) and delivered as the concentration of antioxidants needed for $50 \%$ DPPH radical scavenger in a defined time period $\left(\mathrm{IC}_{50}\right)$. The samples were analyzed in three replications.

$$
\% \text { Inhibition }=\left[\frac{(\mathrm{Ac}-\mathrm{As})}{\mathrm{Ac}}\right] \times 100
$$

Where:

Ac $=$ absorbance control or blank,

As $=$ absorbance with sample or standard.

\section{Cytotoxicity assay}

The cytotoxicity of the ethanolic extract of physalis was investigated by brine shrimp lethality bioassay [20]. Brine shrimp that are hatched is obtained from brine shrimp eggs (Hobby Artemix ${ }^{\circledR}$, Germany), which is mixed with salt, in a conical shaped vessel, for $48 \mathrm{~h}$ they were left in sterile distilled water under constant aeration. Using a capillary glass of ten active nauplii is taken and put into a bottle containing $4.5 \mathrm{ml}$ of brine solution. The $0.5 \mathrm{ml}$ of the ethanolic extract has been added with brine solution ( $4.5 \mathrm{ml}$ ) and stored under light at room temperature for $24 \mathrm{~h}$, and surviving larvae were counted. After incubation, the larvae are counted dead and live in each test. The research was controlled (vehicle-treated) at unequal concentrations $(1-1000 \mu \mathrm{g} / \mathrm{ml})$ with test substances per dose of a set of three tubes. The $\mathrm{LC}_{50}$ values are used to determine the mortality rate of larvae up to $50 \%$, were calculated using probity analysis. Estimated linear correlations were observed when the logarithm of concentration.

\section{Statistical analysis}

Data were presented in means \pm standard deviation and tested for normality. The differences between treatments were analyzed using ANOVA. Significant differences between mean values were calculated using the Duncan Multiple Range Test $(\alpha=5 \%)$. All statistical analysis was performed using Microsoft Excel 2013.

\section{RESULTS}

\section{Nutrition and physicochemical characteristics}

The nutrition and physicochemical characteristics of each part of P. angulata L. are displayed in Tables 1 and 2.

Table 2 showed physicochemical characteristics of each part of physalis with the $\mathrm{pH}$ value ranging from 5.81 to 6.46 , and the total solid ranging from 5.16 to $6.86^{\circ}$ Brix. The color of each part of $P$. angulata used a colorimeter $3 \mathrm{nh}$ to find out the spectrum of reflection of the sample, so we get the color coordinates of CIE L* $a^{*} b^{*}$ coordinates and hue $\left(h^{*}\right)$ (Table 2). Table also shows that the colors of each part of physalis were darker, greener, and less blue, except for fruit and stem bark powder. The plant cell walls breakdown is related to the extracts obtained. The yields of ethanolic extract of each part of physalis ranged from 2.0 to 3.6\% (Fig. 2).

\section{Phytochemical screening}

Phenolic compounds in P. angulata L. ethanolic extracts are found in large quantities in the phytochemical screening process, which proven by the existence of alkaloids terpenoids, tannins, flavonoids, and glycosides. Phytochemical screening is shown in Table 3. 
Table 1: Nutrition composition of $P$. angulata L. powder

\begin{tabular}{|c|c|c|c|c|c|}
\hline \multirow[t]{2}{*}{ Constituent } & \multicolumn{5}{|c|}{ Part of the plant } \\
\hline & ESC & ERC & ELC & EUF & EFC \\
\hline Moisture (\%) & $6.04 \pm 0.41^{\mathrm{e}}$ & $14.31 \pm 0.51^{\mathrm{a}}$ & $9.30 \pm 0.81^{b c}$ & $8.60 \pm 0.28^{d}$ & $9.38 \pm 0.40^{\mathrm{bc}}$ \\
\hline Ash (\%) & $0.87 \pm 0.01$ & $0.91 \pm 0.00$ & $0.90 \pm 0.01$ & $0.85 \pm 0.03$ & $0.87 \pm 0.01$ \\
\hline Protein (\%) & $10.75 \pm 0.00^{\mathrm{d}}$ & $14.06 \pm 0.00^{\mathrm{a}}$ & $2.98 \pm 0.00^{\mathrm{e}}$ & $17.10 \pm 00^{\mathrm{b}}$ & $13.72 \pm 0.00^{c}$ \\
\hline Lipid (\%) & $4.10 \pm 0.13^{\mathrm{de}}$ & $7.39 \pm 0.35^{c}$ & $11.28 \pm 0.35^{\mathrm{a}}$ & $3.65 \pm 0.11^{\mathrm{de}}$ & $9.81 \pm 0.50^{\mathrm{b}}$ \\
\hline Carbohydrates (\%) & $78.24 \pm 0.14^{\mathrm{a}}$ & $63.34 \pm 0.22^{\mathrm{e}}$ & $75.54 \pm 0.23^{\mathrm{b}}$ & $69.80 \pm 0.10^{c}$ & $66.22 \pm 0.23^{d}$ \\
\hline Energy (kcal) & $392.86 \pm 1.73$ & $375.99 \pm 4.03$ & $415.60 \pm 4.07$ & $380.45 \pm 1.39$ & $408.05 \pm 5.42$ \\
\hline
\end{tabular}

Data are expressed as mean \pm standard deviation $(\mathrm{n}=3)$. ESC: Stem bark extract of Physalis angulata L., ELC: Leaf extract of Physalis angulata L., ERC: Rind extract of Physalis angulata L., EUF: Unripe fruit extract of Physalis angulata L., EFC: Ripe fruit extract of Physalis angulata L. a $>\mathrm{b}>\mathrm{c}>\mathrm{d}>\mathrm{e}$, the existence of the same letter in the same line is expressed as the absence of difference. P. angulata L.: Physalis angulata Lour

Table 2: Physicochemical characteristics of P. angulata $\mathrm{L}$.

\begin{tabular}{|c|c|c|c|c|c|c|c|}
\hline \multirow[t]{2}{*}{ Samples } & \multirow[t]{2}{*}{ pH } & \multirow[t]{2}{*}{ Total solid (Brix) } & \multicolumn{5}{|c|}{$\operatorname{Color}(\Delta)$} \\
\hline & & & $\mathbf{L}^{*}$ & $a^{*}$ & $\mathbf{b}^{*}$ & Hue & Preference \\
\hline ESC & 6.59 & 6.86 & 59.817 & -2.788 & 14.927 & +0.003 & Darker, greener, more yellow \\
\hline ERC & 6.46 & 5.56 & 53.498 & 3.492 & 15.903 & +0.004 & Darker, less red, more yellow \\
\hline ELC & 6.33 & 5.16 & 48.410 & -2.168 & 9.593 & +0.003 & Darker, greener, less blue \\
\hline EUF & 5.81 & 5.36 & 55.811 & 7.142 & 19.770 & +0.003 & Brighter, less red, more yellow \\
\hline $\mathrm{EFC}$ & 6.01 & 6.56 & 55.811 & 7.142 & 19.770 & +0.003 & Brighter, less red, more yellow \\
\hline
\end{tabular}

Data are expressed as mean (n=3). ESC: Stem bark extract of Physalis angulata L. , ELC: Leaf extract of Physalis angulata L., ERC: Rind extract of Physalis angulata L., EUF: Unripe fruit extract of Physalis angulata L., EFC: Ripe fruit extract of Physalis angulata $\mathrm{L} . \mathrm{a}>\mathrm{b}>\mathrm{c}>\mathrm{d}>\mathrm{e}$, the existence of the same letter in the same column is expressed as the absence of difference. P. angulata L; Physalis angulata Lour

Total carotenoids content

The result of the total carotenoids of each part of a P. angulata extract is presented in Fig. 3. Fig. 3 showed that total carotenoid compounds contained in the extract range between 6.83 and $20.22 \mu \mathrm{g} / \mathrm{g}$ extract.

\section{TP content, TF content, and antioxidant activity $\left(\mathrm{IC}_{50}\right)$}

The results of the quantitative analysis support the results of previous phytochemical screening, where leaf extracts have a high amount of phenolics compounds. The TP, TF, and antioxidant activity $\left(\mathrm{IC}_{50}\right)$ are shown in Table 4. Table 4 showed that ethanol extract of $P$. angulata has TP content ranged from 15.43 to $144.33 \mathrm{mg} \mathrm{GAE} / \mathrm{g}$ dry weight. The level of antioxidant activity was interrelated with the level of TP content of $\left(\mathrm{R}^{2}\right) 0.857$ (Fig. 4). The results of the study showed that with the high content of total phenols, the stronger the antioxidant activity (with the lowest of $\mathrm{IC}_{50}$ values).

\section{Cytotoxicity}

The cytotoxicity $\left(\mathrm{LC}_{50}\right)$ brine shrimp lethality test of ethanolic extract of each part of the physalis plant evaluated is summarized in Table 5.

\section{DISCUSSION}

This study shows that the ethanolic rind extract of $P$. angulata L. (ERC) had the highest moisture and protein content than other parts $(\mathrm{p}<0.05)$ (Table 1). The protein of the fruit of P. pubescens L. was $31.8 \%$ [21]. Moreover, the fruit of Physalis peruviana has better protein contains [22]. The leaf extract of P. angulata L. (ELC) contained the highest lipid content (11.28\%) followed by EFC>ERC>unripe fruit extract of $P$. angulata L. (EUF) and stem bark extract of $P$. angulata $\mathrm{L}$. (ESC) $(\mathrm{p}<0.05)$. According to Ramadan and Mörsel [23], the fruit of $P$. peruviana $\mathrm{L}$. contains $2 \%$ lipid content, which is $1.8 \%$ (seeds) and $0.2 \%$ (fruit skin). The high content of polyunsaturated fatty acids obtained from peruviana, which has been extracted into oil [23]. A phytochemical in extract plant maintained in $\mathrm{pH}$ value $3-11$ and antioxidant activity influenced by $\mathrm{pH}[24,25]$. ANOVA displayed that the ethanolic extract of the fruit of P. angulata, namely, EUF and $\mathrm{EFC}$, with the highest average values in yields is ESC $>\mathrm{ERC}$ and ELC $(\mathrm{p}<0.05)$ (Table 2).

Table 3 is displayed that leaves and fruit extracts of $P$. angulata have various phenolic compounds. Alkaloids compounds were
Table 3: Phytochemical screening of $P$. angulata $\mathrm{L}$.

\begin{tabular}{llllll}
\hline Constituent & ESC & ERC & ELC & EUF & EFC \\
\hline Alkaloids & & & & & \\
Mayer & - & - & - & - & - \\
Terpenoids & ++ & ++ & ++++ & ++ & +++ \\
Saponin & + & - & ++ & - & - \\
Tannins & ++ & +++ & ++++ & + & +++ \\
Flavonoids & + & ++ & +++ & + & ++ \\
Glycosides & - & ++ & ++++ & + & +++ \\
\hline
\end{tabular}

$(+)$ means positive; (-) means negative. ESC: Stem bark extract of Physalis angulata L. , ELC: Leaf extract of Physalis angulata L., ERC: Rind extract of Physalis angulata L., EUF: Unripe fruit extract of Physalis angulata L., EFC: Ripe fruit extract of Physalis angulata L., P. angulata L.: Physalis angulata Lour

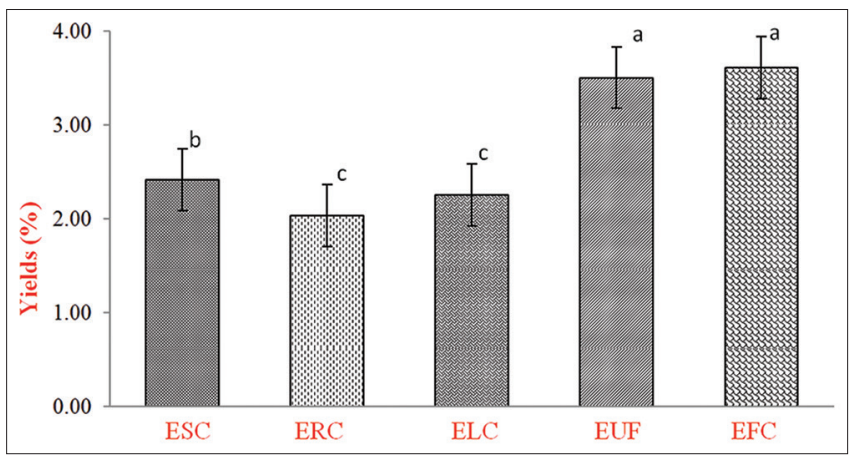

Fig. 2: Yields of ethanolic extracts of Physalis angulata L. Data were expressed as means \pm standard deviation $(n=3)$. ESC: Stem bark extract of $P$. angulata L., ELC: Leaf extract of $P$. angulata $\mathrm{L}$.,

ERC: Rind extract of $P$, angulata L., EUF: Unripe fruit extract of

$P$. angulata L., EFC: Ripe fruit extract of $P$. angulata $\mathrm{L}$. $\mathrm{a}>\mathrm{b}>\mathrm{c}$, same alphabetic in the graphic=no difference

not in ethanolic extract of physalis. The results of this study are an agreement with methods of Andrianto et al. [26], the ethanolic extract of $P$. peruviana leaves contained phenol, flavonoids, tannins, saponins, steroids, and terpenoids. The stem barks of $P$. angulata, obtained by 


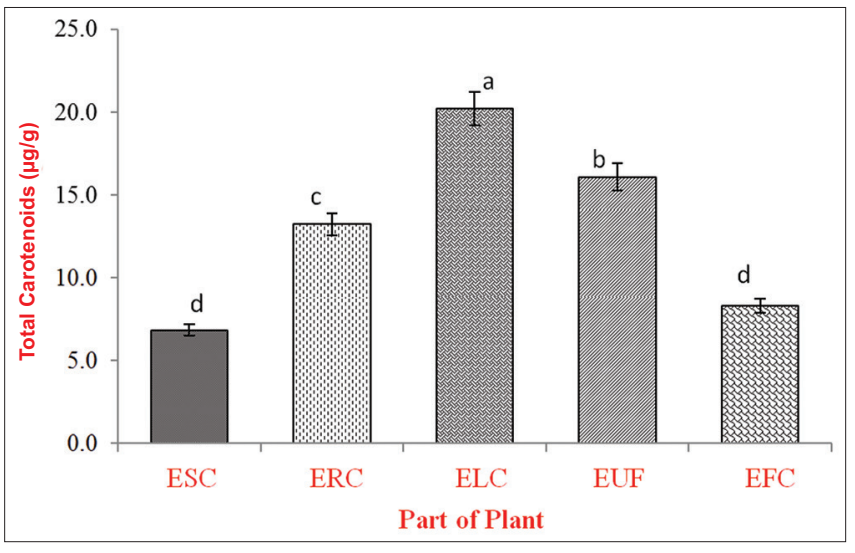

Fig. 3: Total carotenoid of ethanolic extracts of Physalis angulata L. Data were expressed as means \pm standard deviation $(n=3)$. ESC: Stem bark extract of $P$. angulata L., ELC: Leaf extract of $P$. angulata L., ERC: Rind extract of $P$. angulata L., EUF: Unripe fruit extract of $P$. angulata L., EFC: Ripe fruit extract of $P$. angulata $\mathrm{L}$. $a>b>c>d$, same alphabetic in the graphic=no difference

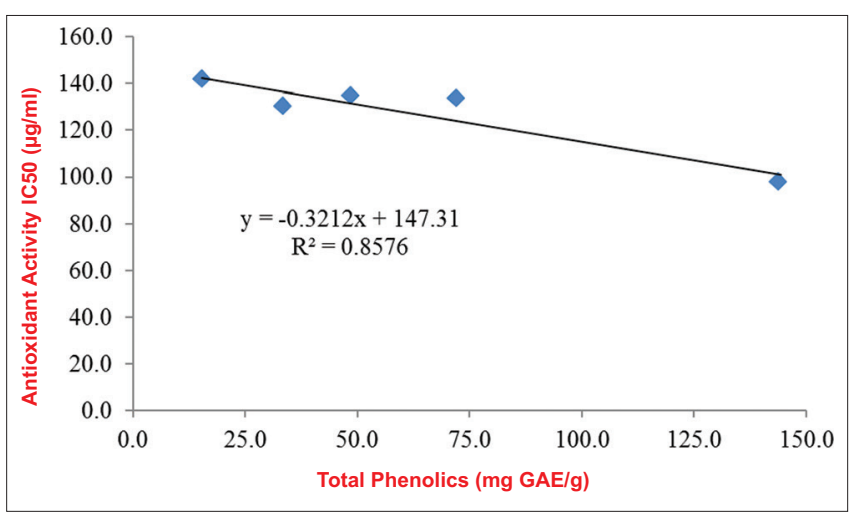

Fig. 4: Relationship between total phenolics content and antioxidants activity of Physalis angulata extract in several parts $(n=3)$

various extraction methods, contained phenol, flavonoid, and tannin compounds [27].

The leaves extract of $P$. angulata (ELC) there is a high amount of total carotenoids $(20.22 \mu \mathrm{g} / \mathrm{ml})$ followed by EUF $>$ ERC $>$ ESC and EFC $(\mathrm{p}<0.05)$ (Fig. 3). This result is in agreement with methods of MierGiraldo et al. [28] who studied that total carotenoid of fruit extract of $P$. peruviana L. ranged between 1.28 and $4.91 \mu \mathrm{g} / \mathrm{g}$ extract. Our findings show that most carotenes found in leaves and fruit extracts.

Meanwhile, Table 4 shows that stem bark from P. angulata by extraction process has the lowest TP content. The TP content in physalis influenced by the polarity of solvents and part of the plant used in the extraction process. Every part of the plant such as leaves, fruit, or roots has various types of phytochemical compounds [9]. Table 4 shows that each part of $P$. angulata has a dissimilar in TP content. The highest of a TP content shows in leaves extracts of $P$. angulata (144.33 mg GAE/g dwt) followed by $\mathrm{ERC}>\mathrm{EUF}>\mathrm{EFC}>\mathrm{ESC}(\mathrm{p}<0.05)$. Moreover, the TF content in high amounts derived from the leaf extract $P$. angulata (ELC) (33.33 mg QE/g dwt) where the scale of TF to TP at 0.23 , followed by ethanol extract of EUF $>$ EFC $>$ ERC $>$ ESC $(p<0.05)$ (Table 4). DPPH free radical inhibition of the ethanol extract $P$. angulata depends on the concentration where the value is expressed as $\mathrm{IC}_{50^{\circ}}$. Based on the results of an analysis of antioxidant activity contained in the ethanolic leaves extract of physalis (ELC), has a high antioxidant activity value with the lowest $\mathrm{IC}_{50}$ value (Table 4). However, the resulting activity remains below the standard gallic acid or ascorbic acid. The extent of the TP
Table 4: TP, TF content, and antioxidant activity of ethanolic extract of $P$. angulata $\mathrm{L}$.

\begin{tabular}{lllll}
\hline Samples & TP (mg GAE/g) & TF (mg QE/g) & TF: TP & IC $_{50}(\mu \mathrm{g} / \mathrm{ml})$ \\
\hline ESC & $15.43 \pm 1.88^{\mathrm{e}}$ & $9.04 \pm 0.04^{\mathrm{e}}$ & 0.58 & 141.07 \\
ERC & $72.27 \pm 4.95^{\mathrm{b}}$ & $10.67 \pm 0.45^{\mathrm{cd}}$ & 0.15 & 133.76 \\
ELC & $144.33 \pm 0.00^{\mathrm{a}}$ & $33.33 \pm 0.00^{\mathrm{a}}$ & 0.23 & 96.97 \\
EUF & $33.60 \pm 1.18^{\mathrm{d}}$ & $22.41 \pm 0.00^{\mathrm{b}}$ & 0.67 & 129.25 \\
EFC & $48.77 \pm 0.94^{\mathrm{c}}$ & $11.91 \pm 0.35^{\mathrm{c}}$ & 0.24 & 134.53 \\
\hline
\end{tabular}

Data are expressed as means \pm standard deviation $(n=3)$. GAE: Gallic acid equivalent; QE: Quercetin equivalent. ESC: Stem bark extract of Physalis angulata L., ELC: Leaf extract of Physalis angulata L., ERC: Rind extract of Physalis angulata L., EUF: Unripe fruit extract of Physalis angulata L., EFC: Ripe fruit extract of Physalis angulata L. a $>\mathrm{b}>\mathrm{c}>\mathrm{d}>\mathrm{e}$, the existence of the same letter in the same column is expressed as the absence of difference. TP: Total phenolics, TF: Total flavonoids, P. angulata L.: Physalis angulata Lour

content of $P$. angulata affects free radical scavenging activity.

Phenolic compounds are known to possess antioxidant activity that can bind active oxygen species and electrophiles [29]. Fig. 4 shows that antioxidant activity of P. angulate of $86 \%$ derived from phenolic compounds, meanwhile $14 \%$ obtained from carotenoids, vitamin, etc. This result in accordance with methods of Maisuthisakul et al. [30] that in 28 Thai plant ethanol extracts showed a close involvement among antioxidant activity and TP. Furthermore, another study said that the different crops there are also similarities correlation analysis [31].

The ethanolic extract of each part of the physalis tested showed nontoxic activity $\left(\mathrm{LC}_{50}\right.$ value more than $\left.1000 \mu \mathrm{g} / \mathrm{ml}\right)$. Meanwhile, not for ripe fruit extract of $P$. angulata $\mathrm{L}$. (EFC) having a value of $\mathrm{LC}_{50}<1000 \mu \mathrm{g} / \mathrm{ml}$ ) [20]. The $\mathrm{LC}_{50}$ values of ethanolic extract for ESC, ERC, ELC, EUF, and EFC were $2297 \mu \mathrm{g} / \mathrm{ml}, 2181 \mu \mathrm{g} / \mathrm{ml}, 2024 \mu \mathrm{g} / \mathrm{ml}, 1682 \mu \mathrm{g} / \mathrm{ml}$, and $924 \mu \mathrm{g} / \mathrm{ml}$, respectively. However, the ethanol extract of physalis has a low value when compared with the amount of value to other plants, except leaves or fruit part of physalis [32,33]. According to Kormin et al. [34], variations in temperature during the process may affect poorly extracted $\mathrm{LC}_{50}$ values. It may be due to the denaturing of some bioactive compounds and other reasons that may only be active when its fresh. The cytotoxic property by ethanolic extract of physalis ripe fruit (EFC) might be due to the presence of a good amount of flavonoid content. A large number of flavonoids in physalis material have reported as antihyperglycemia and anti-hypertension, immunomodulation and antiinflammation effect, and antioxidant activity [7-9].

In the current study, we found that a ripe fruit extract of physalis (EFC) displayed the toxicity with the highest value against $A$. salina brine shrimp larvae at lower $\mathrm{LC}_{50}$ values. The results of this study stated that potential cytotoxic compounds could indicate from the ethanol extract of $P$. angulate $\mathrm{L}$.

\section{CONCLUSION}

The $P$. angulate $\mathrm{L}$. has good nutritional characteristics that contain bioactive compounds that provide health benefits. In color, the powders of each part of physalis were darker, greener, and less blue, except for fruit and stem bark powder. The leaves extract of physalis (ELC) contained the highest total of phenolics and total of flavonoids with a ratio of TF/TP, which is 0.23 . ELC is found to have the highest antioxidant activity (EC50) followed by ERC $>$ EFC $>$ EUF $>$ ESC. The TP content of extract of physalis has a strong correlation with antioxidant activity. Based on the toxicity test (LC50), the ripe fruit extract of physalis (EFC) as cytotoxic. These results provide useful data about the nutritional, antioxidant properties, and toxicity of ethanolic extract of each part of physalis for functional food product uses.

\section{ACKNOWLEDGMENTS}

The authors are grateful to the Ministry of Research and Technology and Higher Education, Republic of Indonesia (KEMENRISTEKDIKTI-RI), 
for financial assistance (No.20/P/PRL_LIPI/INSINAS-1/III/2018) and Indonesian Institute of Sciences (LIPI) for providing access and technical support.

\section{AUTHORS' CONTRIBUTIONS}

Ade Chandra Iwansyah (ACI) and Rohmah Luthfiyanti designed and conducted field research; Wahidiyanti P Julianti performed laboratory analysis; ACI conducted statistical analyses; ACI wrote the manuscript with inputs from all coauthors; ACI had final responsibility for the content. All authors read and approved the final manuscript.

\section{CONFLICTS OF INTEREST}

There are no conflicts of interest in this paper.

\section{REFERENCES}

1. Ekor M. The growing use of herbal medicines: Issues relating to adverse reactions and challenges in monitoring safety. Front Pharmacol 2014:4:177.

2. [MOT-RI] Ministry of Trade. Warta Ekspor Obat Herbal Tradisional. Jakarta: Ministry of Trade, Republic of Indonesia; 2014.

3. Hariyadi P. Industri pangan fungsional Indonesia: Peluang untuk membangun kesehatan bangsa. Food Rev Indones 2015;10:514-7.

4. Popkin BM. Global nutrition dynamics: The world is shifting rapidly toward a diet linked with noncommunicable diseases. Am J Clin Nutr 2006; $84: 289-98$

5. [MOH-RI] Ministry of Health. Riset Kesehatan Dasar (Riskesdas). Jakarta: Ministry of Health, Republic of Indonesia; 2013

6. Kasali F, Fokunang C, Ngoupayo J, Tembe-Fokunang E, Ngameni B, Legrand NB, et al. Evaluation of the antidiabetic properties of hydroalcoholic extract and its fractions from Physalis peruviana L. leaves on streptozotocin-induced diabetic wistar rats. J Dis Med Plants 2016;2:667-73.

7. Pinto Mda S, Ranilla LG, Apostolidis E, Lajolo FM, Genovese MI, Shetty K, et al. Evaluation of antihyperglycemia and antihypertension potential of native peruvian fruits using in vitro models. J Med Food 2009;12:278-91.

8. Adnyana IK, Yulinah E, Maeistuti N, Setiawan F. Evaluation of ethanolic extracts of mullaca (Physalis angulata L.) herbs for treatment of lupus disease in mice induced pristane. Procedia Chem 2014;13:186-93.

9. Kusumaningtyas RW, Laily N, Limandha P. Potential of ciplukan (Physalis angulata L.) as source of functional ingredient. Procedia Chem 2015;14:367-72

10. Ghosh D. Quality issues of herbal medicines: Internal and external factors. Int J Complement Alternat Med 2018;11:2003-50.

11. Yusoff MM, Iwansyah AC. Comparative Evaluation of Total Phenolics and Free Radical Scavenging Activity of Aqueous Extracts of Labisia pumila var. alata from Malaysia and Indonesia. In: International Conference on Biotechnology and Food Science, IEEE, April 1-3, 2011 Bali, Indonesia; 2011. p. 4-8.

12. AOAC. Official Methods of Analysis. Association of Official Analytical Chemist. Arlington, Virginia (US): AOAC; 1990

13. Harborne JB. Phytochemical Methods. London: Chapman and Hall, Ltd.; 1973. p. 49-188.

14. Sofowara A. Medicinal Plants and Traditional Medicine in Africa. Ibadan: Spectrum Books Ltd.; 1993. p. 1-289.

15. Trease GE, Evans WC. Pharmacognsy. $11^{\text {th }}$ ed. London: Brailliar Tiridel Can Macmillian; 1989.

16. Scrob S, Muste S, Has I, Muresan C, Socaci S, Farcas A. Total content of carotenoids in corn landraces and their potential health applications.
Bull UASVM Food Sci Technol 2014;71:296-300.

17. Iwansyah AC, Yusoff MM. Physicochemical, minerals and antioxidant properties of Labisia pumila var. alata of selected geographic origins. AGRIVITA J Agric Sci 2012;34:94-104.

18. Meda A, Lamien CE, Romito M, Miliogo J, Nacoulina O. Determination of the total phenolic, flavonoid, and proline content in burkina fasan money, as well as their radical scavenging activity. Food Chem 2005;91:571-7.

19. Kumaran RJ, Kuranakaran. Antioxidant and free radical scavenging activity of an aqueous extract of Coleus aromaticus. Food Chem 2007;97:109-14.

20. Meyer BN, Ferrigni NR, Putnam JE, Jacobsen LB, Nichols DE, McLaughlin JL, et al. Brine shrimp: A convenient general bioassay for active plant constituents. Planta Med 1982;45:31-4.

21. El Sheikha AF, Zaki MS, Bakr AA, El Habashy MM, Montet D. Biochemical and sensory quality of Physalis (Physalis pubescens L.) juice. J Food Process Preserv 2010;34:3541-55.

22. Rodríguez S, Rodríguez E. Effecto de la ingesta de Physalis peruviana (aguaymanto) sobre la glicemia postprandial en adultos jóvenes. Rev Méd Vallejiana 2007;4:143-52

23. Ramadan MF, Mörsel JT. Oil goldenberry (Physalis peruviana L.). J Agric Food Chem 2003;51:969-74.

24. Jamal JA. Malay traditional medicine, an overview of scientific and technological progress. Tech Monit 2006;23:37-49.

25. Maisuthisakul P. Phenolic constituents and antioxidant properties of some thai plants. In: Rao V, editor. Phytochemicals - a Global Perspective of their Role in Nutrition and Health. Rijeka, Croatia: InTech; 2012.

26. Andrianto D, Anaser G, Untoro M, Fatmawati R, Winda RA, Aisyah S. Pengaruh Ekstrak Daun Ciplukan (Physalis angulata L.) Terhadap Kelarutan Batu Ginjal in vitro. In: Prosiding Seminar Nasional Kimia Unesa; 2012

27. Susanti RF, Garini S, Renaldo IJ, Ananda R, Stenny A. Laporan Penelitian Ekstraksi Batang Physalis angulata Dengan Air Subkritik. Food Technology Study Program; 2013.

28. Mier-Giraldo H, Díaz-Barrera LE, Delgado-Murcia LG, ValeroValdivieso MF, Cáez-Ramírez G. Cytotoxic and immunomodulatory potential activity of Physalis peruviana fruit extracts on cervical cancer (HeLa) and fibroblast (L929) cells. J Evid Based Complementary Altern Med 2017;22:777-87.

29. Zhang D, Hamauzu Y. Phenolics compounds and their antioxidant properties in different tissues of carrots (Daucus carota L.). J Food Agric Environ 2004;2:195-200.

30. Maisuthisakul P, Pasuk S, Ritthiruangdej P. Relationship between antioxidant properties and chemical composition of some Thai plants. J Food Compos Anal 2008;21:229-40.

31. Iwansyah AC, Damanik RM, Kustiyah L, Hanafi M. Relationship between antioxidant properties and nutritional composition of some galactopoietics herbs used in indonesia: A comparative study. Int J Pharm Pharm Sci 2016;8:1236-43.

32. Djajanegara I. Uji sitotoksisitas ekstrak ethanol $70 \%$ herba ciplukan (Physalis angulata Linn.) terhadap sel widr secara in vitro. J Kimia Valensi 2008;1:149-56.

33. Layyina H. Toksisitas Ekstrak Ciplukan (Physalis angulata) Berdasarkan uji Letalitas Larva Udang. Institut Pertanian Bogor. Thesis; 2014.

34. Kormin F, Khan M, Iwansyah AC. Microwave assisted extraction; phytochemical evaluation of Malaysian palm oil trunk epiphytes ferns. Int J Pharm Pharm Sci 2016;8:1-7. 